\title{
IdeAs
}

Idées d'Amériques

$18 \mid 2021$

Frontières dans les Amériques - Intégration, sécurité et migrations

\section{Frontiers in the Americas - critical approaches to migrations, security and integration}

Pierre-Alexandre Beylier, Anne-Laure Amilhat-Szary, Gregory Benedetti and Éric Tabuteau

Translator. Michael Hinchliffe

\section{OpenEdition}

\section{Journals}

\section{Electronic version}

URL: https://journals.openedition.org/ideas/11999

DOI: 10.4000/ideas. 11999

ISSN: 1950-5701

\section{Publisher}

Institut des Amériques

\section{Electronic reference}

Pierre-Alexandre Beylier, Anne-Laure Amilhat-Szary, Gregory Benedetti and Éric Tabuteau, "Frontiers in the Americas - critical approaches to migrations, security and integration", IdeAs [Online], 18|2021, Online since 01 October 2021, connection on 04 November 2021. URL: http:// journals.openedition.org/ideas/11999 ; DOI: https://doi.org/10.4000/ideas.11999

This text was automatically generated on 4 November 2021.

\section{$\Theta \Theta \Theta \Theta$}

IdeAs - Idées d'Amériques est mis à disposition selon les termes de la licence Creative Commons Attribution - Pas d'Utilisation Commerciale - Pas de Modification 4.0 International. 


\section{Frontiers in the Americas - critical approaches to migrations, security and integration}

Pierre-Alexandre Beylier, Anne-Laure Amilhat-Szary, Gregory Benedetti and Éric Tabuteau

Translation : Michael Hinchliffe

\section{Frontiers as laboratories}

1 The Americas can be seen as a prime laboratory for the study of frontiers and how frontiers evolve. During the "world without frontiers" decade, not only has the continent as a whole witnessed multiple regional integration projects, notably MERCOSUR and NAFTA, which have seen countries move closer together and lower customs barriers, but the very same frontiers have also, in recent years, become points of friction on account of a gamut of ever-growing problems, from trafficking in various forms to territorial disputes. These recent developments have suggested to us the interest of a critical examination of the processes involved in the frontiers crisscrossing the Americas in an attempt to characterize them more fully both in terms of what might be specific to the continent and of what might be relevant in terms of worldwide tendencies. Within a global context of developing theory in the study of frontiers, it seems worthwhile to consider how a continent-wide approach might highlight regional specificities and how such an approach might constitute an original contribution to the current epistemological effort (Mezzadra S. and B. Neilson, 2013), (Nail, 2016), (Parker et al, 2012), (Wastl-Walter, 2012).

2 The aim in this issue of IdeAs is to look at frontiers through the prism of two dynamics that seem initially antithetical, integration and border security, while examining their impact on population migration. Not only do these two dynamics, taken up in the contradictory processes of "dismantlement and construction" (Machado De Olivera, $2009: 19)$, structure frontiers that are at present as reticular as they are linear, in as 
much as they help to deal selectively with the flow of globalization (Amilhat-Szary A.L., 2015), but they also fold into each other, thereby ultimately reinforcing the ambivalence of instituted frontiers.

3 As a stage for European colonial appetites, the American continent remained under the direct influence of European powers for almost four centuries, since its (re)discovery in 1492 up until decolonization in the first half of the $19^{\text {th }}$ century. From mere zones of influence to full-blown colonial empires, the Americas became an extension of the Old World and, because they provided inexhaustible resources, a centerpiece of the world economy that was beginning to develop. Since decolonization, they have been a locus where the West has been constantly reinventing the modes of its global leadership [Rouquié A., 1987].

4 Hence the Americas overall share the fact that the frontiers put in place were designed to "organize" the continent (Popescu G., 2011) before any nation states came into existence. More precisely, they arose from an original combination of two forms of territorial appropriation. On the one hand is the logic of colonial conquest by zones (the concept of frontier) the aim of which is to valorize wilderness spaces - a logic theorized in terms of the United States by Frederick Turner (Turner F., 1964) - and, on the other hand, the imposition of a western conception of space in terms of an organized network (the concept of boundary) (Perrier Brislé L., 2007).

5 This double logic was deployed at the expense of the Amerindian peoples present throughout the continent. The colonial powers and later, the newly independent states, used frontiers - a system of spatial organization foreign to indigenous peoples - to enslave and dominate them by restricting their mobility, parking them on reservations or within certain countries, or else by forcing on them a "national" identity not their own (Rensink B., 2018). The "violence" inherent in frontiers (Jones R., 2017) is nothing new and, as far as the Americas are concerned, their imposed, exogenous character, even though some hold them to have pre-existed, binds this violence deep into the continent's history, with all the attendant questions of legitimacy and identity.

6 Over and beyond the historical traits proper to them, American frontiers have characteristics similar to frontiers throughout the world. In this wider context, dominated by soaring globalization and the repercussions of nine-eleven, frontiers are the scene of the a priori antithetical, but nonetheless concomitant, phenomena of "debordering" and "rebordering" (Herzog L. and C. Sohn, 2019) : on the one hand, they tend to lose both their visibility and function in order to facilitate the flow of commerce and finance, whereas, on the other hand, they tend to harden in order to restrict mobility generally and to stigmatize certain types of migration. The result is a situation involving differentiation as to how a given frontier is crossed according to a combination of individualized criteria amounting to what have been called disparate frontiérités or "borderities" (Amilhat Szary A. L. and F. Firaut, 2015).

7 The apparent defunctionalization of frontiers (Eva F., 1996) started to gain momentum in the 1990s when countries embracing the flow of globalization set up trade agreements such as NAFTA in North and MERCOSUR in South America or even UNASUR (USAN) covering the entire hemisphere. With their aim of promoting regional integration, such agreements generated a particular attitude towards frontiers, seen more as a "resource" than a "stigmata". (Amilhat-Szary A.L., 2015 : 85). Integration was also considered a "stabilizing factor" (Medina L., 2009 :41) in a continent where some 
regions had been involved in recurrent border quarrels since the $19^{\text {th }}$ century and where, in some cases, frontiers are still in dispute today (Medina L., 2009 :36-37).

However, just as American frontiers were opening up to exchange and market economy, some of their roles were being simultaneously reinforced. Since nine-eleven, the threat of international terrorism has meant that American countries, starting with the US have revised the functioning of their international limits. With territorial security in mind, frontiers have become sites deploying high-tech surveillance and control, culminating in the construction of actual "walls", symptomatic of the phenomenon of refrontierization and the violence which attends it. Frontiers hitherto virtually unguarded, such as the Canada-US border or the Latin American dyad or sister-country borders, are now equipped with a whole range of new devices, from drones to ground sensors and towers with night-vision cameras (Beylier P.A., 2016). The fight against terrorism may be uppermost in discourse, but it seems in practice to serve as a pretext for the control of migration, now the explicit target of all these measures. The COVID-19 crisis, with frontiers shutting down one after the other, has amplified this phenomenon beyond precedent and the piece by Nicolli Bernardes Ribeiro looks at the situation this has produced at the frontiers of Brazil which illustrates the contradiction between nationalist discourse and the long period during which pandemic-related close-down was rejected.

It is, then, with this continental perspective that the present articles tackle the notion of frontier the problematic definition of which is now clearly apparent. The article by Jean Clot on "porous frontiers" illustrates the way discourse has adapted to the present shifting context. Complementarily, the piece by François-Michel Le Tourneau highlights the "reticular logic" of gold-panners in French Guiana who take advantage of the lack of surveillance in distant frontier zones, thereby counteracting the "area logic" according to which frontiers remain for States tools for the exercise of sovereignty and surveillance. Disputed, transgressed, transcended, reinforced or integrated, frontiers are clearly central to political debate in the Americas. In public discourse, the frontier question seems to have superseded the promotion of continentwide integration within both NAFTA and its successor CUSMA and MERCOSUR, but also on the scale of North and South America (UNASUR), all of which were regional groupings presented as models in the 1990s.

However, "border work" is not, in the Americas as elsewhere, exclusive to dominant actors, it is the result of practices happening "at the bottom" (Rumford C., 2008) and the articles here emphasize how the inhabitants of frontier regions interact with international norms, confronting and defying them, as is particularly the case with gold-panning in Guiana, which seems to shake free from these norms and be carried out "a-nationally", as F-Michel Le Tourneau shows. Because a frontier is an "identity marker" (Piernay J.L., 2005 : 206), it brings to the fore questions concerning the link between identity, territory and frontier. And such questions are the more pressing for the fact, on this continent, "State came before nation" (Medina L., 2009: 38). The role assigned to frontiers in "national cohesion" (ibid) gains importance in as much as it may come into conflict with representations in border communities among which the interpretation autochthonous peoples have of frontier construction can be an essential factor (Nates Cruz B., 2013). As the studies gathered here show, the primary subject is often that of negotiation and confrontation between fixed regional populations and 
mobile populations also present, in a context where the question of migration is seen as a central problem in American frontier spaces today.

\section{Are security and migration at American frontiers necessarily linked?}

11 The nine-eleven attacks - and more generally the emergence of an international terrorist threat present in Latin America as early as the 1980s with the Buenos Aires attacks - modified the role of frontiers. The emergence of "Fortress America" (Alden E., 2008; Andreas P., 2003 ; Noble J., 2004) has been amply described with reference to North America, but the phenomenon of "rebordering" also concerns Latin America. Hence, throughout continent, can be seen policies involving original reinterpretations of main worldwide tendencies in frontier management, one example of which is the massive, unprecedented deployment of security measures at Brazilian frontiers occurring without any real curbing of growing international exchange both legal and illegal (smuggling, drug trafficking, etc.) (Dorfman A. et al, 2014 ; Dorfman A. et al, 2017).

12 The article by Beatriz Zepeda on the work of security officers at the GuatamaltoMexican border or the study by Cléa Fortuné of the interpretation of security by the transfrontier community of Douglas (Arizona) / Agua Prieta (Sonora), both provide a nuanced view of the everyday activity and negotiations among people that go into the construction of the grand overall paradigm of "security". Hence the material aspects of this dynamic and the ways in which the process is acted out territorially are matters of interest. Historical approaches that renew the question of territorial border conflict and offer different levels of appreciation help to bring about a shift in national and nationalist stories.

13 The various policies enacted in the Americas since the early 2000s are particularly illustrative of the phenomenon of "rebordering" being played out all over the world. The studies gathered here look at the implementation of these policies and their implications for transfrontier relations in a comparative perspective (cf. the articles by Jean Clot or Laurence Cros) which has the advantage of highlighting the dynamic running through North America and of linking together the two halves of the continent (Brunet-Jailly E., 2007 ; Konrad V. et al, 2008).

Over and against the shared phenomenon structuring them, each American frontier carries its specificity owing to the fact that the role of the frontier from one country, or indeed from one region, to the next is different (Machado De Oliveira T.C., $2009: 20$ ) : American frontiers show in fact "a huge variety", in Latin America particularly where there are more of them. From "remote frontiers" dividing marginal regions whose territory turns its back on the frontier (Argentine/Chile, Paraguay/Brazil), or "capriccio frontiers" characterized by illegal transfrontier links, especially in newly urbanized zones (Costa Rica/Nicaragua, Mexico/Guatemala), or again "vibrant frontiers" drawing their dynamism from a high population density and a good many comparative advantages (Brazil/Uruguay, Peru/Ecuador, Mexico/US), not forgetting "protocol frontiers", regions instrumentalized by the central power in an attempt to encourage their "dynamization" or else in a top-down approach to the combat against illegal traffics (Chile/Argentine, Haiti/ Dominican Republic), it is clear that the types of frontier are legion (Machado De Oliveira T.C., 2009 :28-30). Across them, various 
degrees of transfrontier cooperation occur, leading to the rise of inter-territorial, or socalled paradiplomatic relations (Gonzalez Miranda, S. et al., 2016).

The crossing of frontiers and the increasing cost in human life incurred appear today to be essential elements for an understanding of American frontiers (De Leon J. and M. Wells, 2015). some of the articles in this dossier (those of Marie-Laure Coubès or Jean Clot) show graphically how crossing the line can now only be apprehended via multiple factors. Not only must intracontinental flows to do with work-seeking mobility be analyzed, but also the situation of the Americas in relation to large-scale migratory strategies involving ever greater numbers of people attempting, for example, to reach North America from Africa by crossing the Atlantic on the old slave-trade routes and trying their luck on long, perilous northward treks. Here questions of risk and vulnerability come to the fore, together with the strategies employed by frontier communities to carry out their lives in conditions of insecurity (cf. the piece by Cléa Fortuné) and reinterpret in their own way international injunctions. The development of illegal activities throughout the Americas (drug trafficking, illegal immigration, cartels etc.) cannot be understood without reference to their causes, ramifications and implications for local populations or to the policies put in place to curb them. All of which should not leave aside the many and varied ways in which local populations deal daily with the frontier particularly in terms of education and health (cf. the articles by Elizabeth Fauquert or Isabelle Sinic).

Because frontiers are spaces in perpetual evolution, the aesthetic and imaginary expressions of which also shift rapidly (Rodney L., 2017 ; Amilhay-Szary A.L., 2014), the mediation of art appears as an essential point of entry into imaginations of the line for any understanding of how American frontiers are evolving. The study Marion Gautreau has made of a photographic approach to the Mexico-Us border via a retrospective analysis of the work of Elsa Medina and Francisco Mata Rosa covering 40 years, corresponds to this necessity.

\section{How the articles in this edition are grouped}

17 The studies to be found in this edition of IdeAs deal with their common overall topic in three complementary ways. Three of them look at the definition of security, showing, on the one hand, its multifaceted and multi-scaled nature and, on the other, the importance of the interpretation local actors have of the wider, global stakes. These are : the article by Beatriz Zepeda, "Security on the Mexico-Guatemala border. Looking at risks and threats from the point of view of the heads of security in the two countries", the article by François-Michel Le Tourneau, "The Frontier? Which frontier? The transnational dynamics of illegal gold-panning in French Guiana" and the article by Nicolli Bernardes Ribeiro, "Pandemic contingency and migratory impacts : an analysis of administrative measures enacting the closure of the frontier between Brazil and Venezuela".

The second grouping centers on the question of migration and examines the complex link between migration and the problematics of security. These articles are : the study by Marie-Laure Coubès, "From undocumented Mexican workers to Central American asylum-seeking families: the transformation of migrational flux over the Mexico-Us border 2005-2020", the essay by Laurence Cros, "Requests for asylum on the US- 
Canadian border: Canada / US Safe Third Country Agreement and Canadian values", and the piece by Jean Clot, "Is the Mexico-Guatemala border a 'porous' frontier ?".

The third and final grouping adds stimulating nuances to the oftentimes caricatural opposition between migration and security, showing that security is negotiated on a daily basis by practices that modify its terms. What Cléa Fortuné shows to be the case overall with reference to one urban agglomeration in "(In)security in frontier cities? A study of Douglas (Arizona) and Agua Prieta (Sonora)" appears also in terms of educational practices in the article by Isabelle Sinic "US/Mexican cooperation: what educational perspectives exist for transnational school children? Is the schooling of binational minors a new form of transfrontier cooperation?" or in terms of frontier medical practices in the study by Elisabeth Fauquert, "Patients without frontiers : socio-economic factors determining medical tourism in the US". And finally, in "Observing the line. The US-Mexican-border seen through the camera lenses of Elsa Medina and Francsisco Mata Rosas", Marion Gautreau offers a study whose historical approach meshes with contemporary analyses and extends them through its artistic dimension.

\section{Openings}

Moving beyond the survey proposed here, certain subjects need further attention for a better understanding of how American frontiers are evolving. The question of maritime borders, a powerfully contentious subject, especially in Central America (Medina L., $2009: 40$ and Medina L., 2001), requires more extensive study on the scale of the entire continent. This problem leads into the question of the exterior frontiers of the continent, particularly in the Arctic (Nicol H. et al, 2009). It also involves, more generically, the whole environmental dimension of frontiers (Guyot S., 2011; Wadewitz L., 2012) which assumes special relevance in the Americas where a majority of international limits pass through sparsely populated zones.

21 Lastly, it should not be forgotten that the American continent is crisscrossed by myriad non-geopolitical frontiers, social and racial in particular. The specific subject of urban frontiers (Chevalier J. et al, 2004) in areas of the continent that share the same neoliberal-based economic development, raises a host of question as to their segmentation. It remains to build up intersectional approaches in order to explore more fully the multidimensional nature of American frontiers.

\section{AUTHORS}

\section{PIERRE-ALEXANDRE BEYLIER}

Pierre-Alexandre Beylier est actuellement maître de conférences en études nord-américaines à

l'université Grenoble-Alpes. Ancien élève de l'Ecole Normale Supérieure de Cachan et Agrégé

d'anglais, il a effectué une thèse à l'Université Paris 3-Sorbonne Nouvelle, portant sur les 
mutations qu'a connues la frontière Canada/Etats-Unis depuis le 11 septembre 2001. Il a publié aux Presses Universitaires de Rennes un ouvrage sur ce sujet : Canada/Etats-Unis : les enjeux d'une frontière. Il s'intéresse désormais aux questions relatives aux communautés frontalières et aux villes-frontière.

\section{ANNE-LAURE AMILHAT-SZARY}

Anne-Laure Amilhat Szary est professeure à l'Université Grenoble-Alpes. Ancienne élève de l'ENS Fontenay, agrégée de Géographie et membre honoraire de l'IUF, c'est une géographe politique qui analyse les frontières. Elle développe des recherches concernent les interrelations entre espace et art dans les lieux contestés et construit un musée imaginaire du border art. Cofondatrice du collectif antiAtlas des frontières (http://www.antiatlas.net/), elle anime le Performance Lab dédié à la Recherche-Création.

Auteure de : Après les frontières, avec la frontière (2006, avec M.-C. Fourny), Qu'est-ce qu'une frontière aujourd'hui? (2015), Borderities, the Politics of Mobile Borders (2015, avec F. Giraut), Histoires de frontières, une enquête sud-africaine (2017, collectif), Géopolitique des frontières. Découper la terre, inventer une vision du monde (2020), Frontières (2020, avec G. Hamez)

\section{GREGORY BENEDETTI}

Gregory Benedetti, agrégé d'anglais et docteur en civilisation américaine, est maître de conférences à l'Université Grenoble Alpes, et membre de l'Institut des langues et des cultures d'Europe, Amérique, Afrique, Asie et Australie. Ses recherches portent essentiellement sur la question raciale aux États-Unis, et plus particulièrement sur la communauté afro-américaine, tant sur le plan politique que culturel. Ses premières publications s'intéressaient notamment à la nouvelle génération d'hommes politiques noirs, dont Barack Obama est devenue la figure tutélaire, mais non exclusive, en devenant président des États-Unis en 2008. Ses travaux s'intéressent également à l'histoire et la politique afro-américaine dans son ensemble, ainsi qu'à la représentation de la communauté noire dans les productions culturelles comme les séries télévisées. Il a dernièrement travaillé sur les élections présidentielles américaines en coorganisant une journée d'études à l'Université Grenoble Alpes. Il est membre de l'Association française d'études américaines depuis 2008.

\section{ÉRIC TABUTEAU}

Professeur des Universités, Université d'Orléans.

UFR des lettres, langues et arts. 